\title{
Actions for early detection of breast cancer in two municipalities in the Western Amazon
}

\author{
Ações para a detecção precoce do câncer de mama em dois municípios da Amazônia Ocidental \\ Acciones para la detección precoz del cáncer de mama en dos municipios de la Amazonía occidental
}

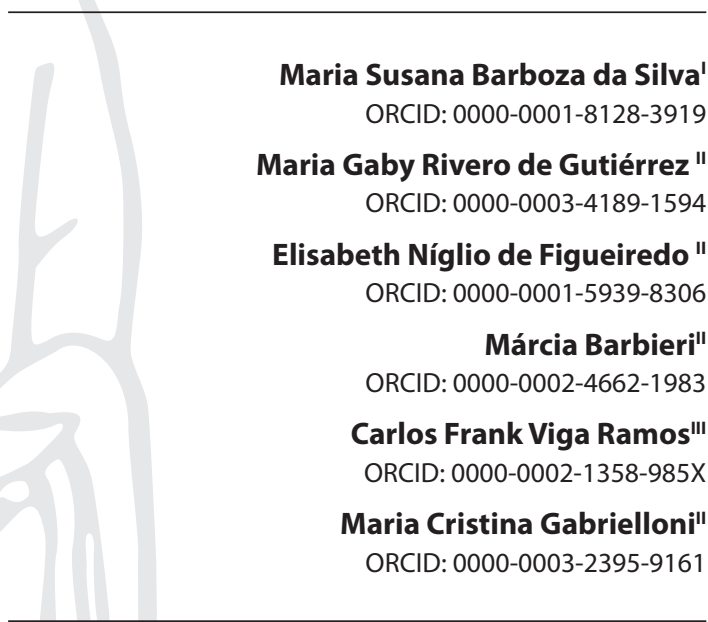

'Universidade Federal do Acre. Cruzeiro do Sul, Acre, Brazil. "Universidade Federal de São Paulo. São Paulo, São Paulo, Brazil. I' Universidade Federal do Acre. Rio Branco, Acre, Brazil.

How to cite this article: Silva MSB, Gutiérrez MGR, Figueiredo EN, Barbieri M, Ramos CFV, Gabrielloni MC. Actions for early detection of breast cancer in two municipalities in the Western Amazon. Rev Bras Enferm.2021;74(2):e20200165. doi: http://dx.doi.org/10.1590/0034-7167-2020-0165

\section{Corresponding author:}

Maria Susana Barboza da Silva E-mail: susan_enfe@hotmail.com

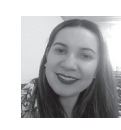

EDITOR IN CHIEF: Antonio José de Almeida Filho ASSOCIATE EDITOR: Fátima Helena Espírito Santo

Submission: 07-15-2020 Approval: 11-11-2020

\begin{abstract}
Objective: to assess the implementation of actions for early detection of breast cancer in Primary Care and to verify the adequacy of these actions with the Ministry of Health recommendations. Method: a cross-sectional study conducted from September 2017 to March 2018 with 736 women registered in Basic Health Units in two municipalities in Acre. For data collection, a validated questionnaire was used. In statistical analysis, the chi-square test or Fisher's exact test was applied. Results: the frequency of mammography was $42 \%$. Of the women at standard risk for breast cancer, only $5,8 \%$ underwent mammography properly. Conclusion: there was a low compliance of early detection actions to the Ministry of Health recommendations; thus, the need to adopt measures to increase professionals' adherence to government proposals is highlighted, as well as continuous actions assessments.

Descriptors: Breast Neoplasms; Primary Health Care; Early Detection of Cancer; Mass Screening; Nursing.
\end{abstract}

\section{RESUMO}

Objetivo: avaliar a realização das ações de detecção precoce do câncer de mama na Atenção Primária e verificar a adequação dessas ações com as recomendações do Ministério da Saúde. Método: estudo transversal realizado de setembro de 2017 a março de 2018 com 736 mulheres cadastradas em Unidades Básicas de Saúde em dois municípios do Acre. Para a coleta de dados, utilizou-se um questionário validado. Na análise estatística, aplicou-se o Teste Qui-Quadrado ou Exato de Fisher. Resultados: a frequência na realização da mamografia foi de $42 \%$. Das mulheres com risco padrão para o câncer de mama, apenas 5,8\% realizaram a mamografia adequadamente. Conclusão: evidenciou-se baixa conformidade das ações de detecção precoce às recomendações do Ministério da Saúde. Dessa forma, destaca-se a necessidade de adoção de medidas para aumentar a adesão dos profissionais às propostas governamentais, assim como avaliação contínua das ações.

Descritores: Neoplasias da Mama; Atenção Primária à Saúde; Detecção Precoce de Câncer; Programas de Rastreamento; Enfermagem.

\section{RESUMEN}

Objetivo: evaluar el desempeño de las acciones de detección precoz del cáncer de mama en Atención Primaria y verificar la adecuación de estas acciones a las recomendaciones del Ministerio de Salud. Método: estudio transversal realizado de septiembre de 2017 a marzo de 2018 con 736 mujeres inscritas en Unidades Salud Básica en dos municipios de Acre. Para la recolección de datos se utilizó un cuestionario validado. En el análisis estadístico se aplicó dos pruebas. Resultados: la frecuencia de mamografías fue del $42 \%$. De las mujeres con riesgo estándar de cáncer de mama, solo el 5,8\% se sometió a una mamografía correctamente. Conclusión: hubo una baja conformidad de las acciones de detección precoz a las recomendaciones del Ministerio de Salud, por lo que se destaca la necesidad de adoptar medidas para incrementar la adherencia de los profesionales a las propuestas gubernamentales, así como la evaluación continua de las acciones.

Descriptores: Neoplasias de la Mama; Atención Primaria de Salud; Detección Precoz del Cáncer; Tamizaje Masivo; Enfermería. 


\section{INTRODUCTION}

Breast cancer is the most common cancer in the female population. According to world statistics, in 2018, an estimated 2.1 million new cases of cancer and 627 thousand deaths from the disease ${ }^{(1)}$. In Brazil, 59,700 new cases of breast cancer were expected for 2019 , corresponding to $29.5 \%$ of all female malignant tumors and an incidence rate of 56/100 thousand. In 2016, 16,069 deaths in women from breast cancer were registered, being the main cause of cancer death among Brazilian women ${ }^{(2)}$.

In Brazil, studies show that from the 1990s there was a decline in mortality rates due to the disease in the capitals of southeast and south regions. On the other hand, there was a great increase in deaths among women in cities in the interior, especially in north and northeast regions ${ }^{(3-4)}$. This increase has been attributed, above all, to the delay in diagnosis and application of appropriate therapy for the failure to implement early detection programs and the difficulty of access to specialized treatment ${ }^{(5)}$. Approximately $40 \%$ of breast cancer cases are diagnosed in late stages (III and IV), with the highest proportion of cases being observed in northern Brazil (42\%), reducing the chances of cure for women and compromising good prognosis ${ }^{(6-7)}$.

There is worldwide evidence that the effectiveness of early detection actions combined with adequate therapy reduces mortality from this cancer and increases the chances of survival(4-5). Following this guidance, in 2004, the Ministry of Health (MoH), through a Consensus Document, recommended in Primary Health Care (PHC): screening for breast cancer through biennial mammography (MMG) in women with standard risk between 50 and 69 years; annual, from 35 years old for high risk; annual performance of clinical breast examination (CBE) in women at standard risk between 40 and 69 years old and at 35 years old for high risk women ${ }^{(8)}$.

However, these recommendations have been updated. Thus, in 2015, the MS published the Guidelines for Early Detection of Breast Cancer, recommending MMG as the main method for screening breast cancer ${ }^{(9)}$. Scientific evidence has shown that its contribution reduces mortality by 30 to $50 \%$ from this disease when screening is performed every two years in women aged 50 to 69 years $^{(10)}$.

Despite the growing trend in performing MMG exams in the target population, recent studies have shown that coverage is still low in women with greater social vulnerability, closely related to poverty and low education in the population ${ }^{(11-13)}$. According to data from the Outpatient Information System of the Unified Health System (SIASUS - Sistema de Informação Ambulatorial do Sistema Único de Saúde), the supply of screening mammograms in SUS (Sistema Único de Saúde - Unified Health System) for the 50 to 69 age group increased by 19\% between 2012 and 2017; however, north and center-west regions had low coverage of the exam when compared to other regions ${ }^{(2)}$.

Considering cancer incidence, increased mortality, less access to early detection actions and low mammographic coverage in target women in norther $\operatorname{Brazil}^{(2,4,13)}$, it became relevant to carry out this research in the municipalities of Cruzeiro do Sul and Rodrigues Alves, state of Acre, where health coverage is provided entirely through Basic Health Units (BHU). This makes it possible to carry out articulated actions for early detection of breast cancer.

\section{OBJECTIVE}

To assess the implementation of actions for early detection of breast cancer in Primary Care and to verify the adequacy of these actions with the Ministry of Health recommendations.

\section{METHOD}

\section{Ethical aspects}

This study followed the legal ethical precepts established for research with human beings. The research project was approved by the Research Ethics Committee of Universidade Federal de São Paulo (UNIFESP). All participants signed the Informed Consent Form (ICF).

\section{Design, place of study and period}

This is an epidemiological, cross-sectional study guided by STROBE, carried out in BHU in the urban area of the municipalities of Cruzeiro do Sul and Rodrigues Alves, AC, from September 2017 to March 2018.

\section{Population, sample, and inclusion and exclusion criteria}

The study population consisted of women using SUS, aged 35 to 69 years, who attended the BHU of the urban area of Cruzeiro do Sul and Rodrigues Alves. Thus, BHU with more than 2 years of operation and users in the age group of 35 to 69 years with follow-up for more than or equal to 2 years at $\mathrm{BHU}$ were eligible for the study. Two independent sampling plans were carried out. For Rodrigues Alves, a sampling plan was made considering a sample design stratified by BHU and age group, in which all $\mathrm{BHU}$ in that municipality would be visited with the final sample proportional to the size of each BHU and age group. In the case of Cruzeiro do Sul, a two-stage sample design was carried out due to the greater complexity and size of this municipality.

In Cruzeiro do Sul, sampling by conglomerates was used, with draws in two stages and the probability of drawing the conglomerate proportional to its size. In a first stage, a draw of $4 \mathrm{BHU}$ was carried out and then a systematic collection of 137 women per BHU was obtained, resulting in a sample of 548 women. For Rodrigues Alves, the sample design was stratified by $\mathrm{BHU}$ and age group, with a sample proportional to the size of the strata, the sample size calculated was 188 women, divided into $2 \mathrm{BHU}$ according to $\mathrm{BHU}$ size and age group. Thus, the sample size for this study resulted in 736 women.

Urban area BHU constituted up to September 2015 and users in the age group between 35 and 69 years with a follow-up of at least two years in the selected BHU were included. Rural area $\mathrm{BHU}$ were excluded.

\section{Study protocol}

Data were obtained through a structured interview using a questionnaire constructed and validated ${ }^{(14)}$. The sociodemographic variables analyzed and self-reported by users were age categorized into three age groups (35-39 years, 40-49 years, 
50-69 years), marital status (single, married, widow, separated, divorced, common-law marriage), race or color (yellow, white, indigenous, black, and mixed ethnicity). Education (illiterate/ incomplete elementary school, complete elementary school/ incomplete middle school/complete middle school/incomplete middle school, complete high school/incomplete higher education, complete higher education) and socioeconomic stratum (A - corresponding to an average household income $=20,272.56$, B1 - 8,695.88, B2 - 4,427.36, C1 - 2,409.01, C2 - 1,446.24 and DE - 639.78) were analyzed according to the Brazilian Economic Classification Criterion of the Brazilian Association of Research Companies of 2015. The variables on high risk for breast cancer assessed as indicated by the $\mathrm{MoH}$ were family history of breast or ovarian cancer, age of the affected person, relationship of the family member who had cancer, if cancer reached one or both breasts. The variables measured regarding the actions for early detection of breast cancer were MMG (yes, no, MMG frequency). The interviews were conducted before or after the woman's care at $\mathrm{BHU}$, in a comfortable area, after consent and signing the ICF.

\section{Analysis of results, and statistics}

Data were stored and processed, using an Excel ${ }^{\circledast}$ spreadsheet version 2010. Descriptive analysis was performed for each of the variables grouped by age group and risk of breast cancer. For descriptive analysis of MMG adequacy, the correspondence between the $\mathrm{MoH}$ recommendation with the information obtained by users regarding their age, performance of tests, frequency of tests performed and the presence or not of high risk for breast cancer was considered. The software $\mathrm{R}^{\circ}$ Core Team 2018 was used for statistical analysis. Pearson's chi-square test or Fisher's exact test was applied to compare the proportions between groups. In all statistical analysis, a significance level of 5\% (p $<0.05)$ was adopted.

\section{RESULTS}

Of the 736 women, $82.3 \%$ lived in the urban area, $40.1 \%$ were married, $76.4 \%$ self-reported as having mixed ethnicity, $48.2 \%$ were illiterate or had incomplete elementary school education and $63.9 \%$ belonged to class D-E. There was a statistically significant difference in marital status in relation to age groups $(p<0.01)$. Most women with a common-law marriage belonged to the age group 35 to 39 years; on the other hand, widowed were between 50 and 69 years old. Education and income also had statistically significant results between age groups $(p<0.01)$. Women aged 50 to 69 had less education and had a lower income than those aged 35 to 39 and those aged 40 to 49 (Table 1).

In relation to the municipalities analyzed, it was found a higher percentage of mammograms performed among women aged 50 to 69 years, and this test was less performed in users between 35 and 39 years old. For women studied in the age group recommended by the $\mathrm{MoH}$ ( 50 to 69 years), in both municipalities, more than $50 \%$ reported having never had MMG before. There was a statistically significant difference between municipalities in relation to MMG frequency among women aged 40 to 49 years ( $p=0.0178$ ), the percentage of tests performed annually was higher in Rodrigues Alves (62.5\%) than in Cruzeiro do Sul (26.7\%) (Table 2).

Table 1 - Percentage distribution of sociodemographic characteristics of women according to age group in Cruzeiro do Sul and Rodrigues Alves, Acre, Brazil, 2017-2018

\begin{tabular}{|c|c|c|c|c|c|}
\hline & TOTAL & 35 to 39 & 40 to 49 & 50 to 69 & *p value \\
\hline TOTAL SAMPLE & 736 & $230(31.3 \%)$ & $247(33.6 \%)$ & $259(35.2 \%)$ & \\
\hline Origin & & & & & 0.4973 \\
\hline Urban area & $606(82.3 \%)$ & $195(84.8 \%)$ & $200(81.0 \%)$ & $211(81.5 \%)$ & \\
\hline Rural area & $130(17.7 \%)$ & $35(15.2 \%)$ & $47(19.0 \%)$ & $48(18.5 \%)$ & \\
\hline Marital status & & & & & $<0.01$ \\
\hline Single & $129(17.5 \%)$ & $41(17.8 \%)$ & 45 (18.2\%) & $43(16.6 \%)$ & \\
\hline Married & $295(40.1 \%)$ & 89 (38.7\%) & $115(46.6 \%)$ & 91 (35.1\%) & \\
\hline Widow & $63(8.6 \%)$ & $4(1.7 \%)$ & $7(2.8 \%)$ & $52(20.1 \%)$ & \\
\hline Separated & $31(4.2 \%)$ & $5(2.2 \%)$ & $11(4.5 \%)$ & $15(5.8 \%)$ & \\
\hline Divorced & $27(3.7 \%)$ & $8(3.5 \%)$ & $6(2.4 \%)$ & $13(5.0 \%)$ & \\
\hline Common-law marriage & $191(26.0 \%)$ & $83(36.1 \%)$ & $63(25.5 \%)$ & $45(17.4 \%)$ & \\
\hline Color or race & & & & & 0.4202 \\
\hline Yellow & $24(3.3 \%)$ & $6(2.6 \%)$ & $7(2.8 \%)$ & $11(4.2 \%)$ & \\
\hline White & $65(8.8 \%)$ & $20(8.7 \%)$ & $22(8.9 \%)$ & $23(8.9 \%)$ & \\
\hline Indigenous & $5(0.7 \%)$ & $1(0.4 \%)$ & $1(0.4 \%)$ & $3(1.2 \%)$ & \\
\hline Black & $80(10.9 \%)$ & $21(9.1 \%)$ & $22(8.9 \%)$ & $37(14.3 \%)$ & \\
\hline Mixed ethnicity & $562(76.4 \%)$ & $182(79.1 \%)$ & 195(78.9\%) & $185(71.4 \%)$ & \\
\hline Education & & & & & $<0.01$ \\
\hline Illiterate or incomplete elementary school & $355(48.2 \%)$ & $73(31.7 \%)$ & $101(40.9 \%)$ & $181(69.9 \%)$ & \\
\hline Complete elementary school or incomplete middle school & $127(17.3 \%)$ & $42(18.3 \%)$ & $42(17.0 \%)$ & $43(16.6 \%)$ & \\
\hline Complete middle school/incomplete high school & $68(9.2 \%)$ & $30(13.0 \%)$ & $26(10.5 \%)$ & $12(4.6 \%)$ & \\
\hline Complete high school/incomplete higher education & $130(17.7 \%)$ & $62(27.0 \%)$ & $55(22.3 \%)$ & $13(5.0 \%)$ & \\
\hline Complete higher education & $56(7.6 \%)$ & $23(10.0 \%)$ & $23(9.3 \%)$ & $10(3.9 \%)$ & \\
\hline Socioeconomic stratum ${ }^{* *}$ & & & & & $<0.01$ \\
\hline B1 & $1(0.1 \%)$ & - & $1(0.4 \%)$ & _ & \\
\hline B2 & $7(1.0 \%)$ & $2(0.9 \%)$ & $2(0.8 \%)$ & $3(1.2 \%)$ & \\
\hline C1 & $64(8.7 \%)$ & $29(12.6 \%)$ & $21(8.5 \%)$ & $14(5.4 \%)$ & \\
\hline C2 & 194(26.4\%) & $70(30.4 \%)$ & $73(29.6 \%)$ & $51(19.7 \%)$ & \\
\hline $\mathrm{D}-\mathrm{E}$ & $470(63.9 \%)$ & $129(56.1 \%)$ & $150(60.7 \%)$ & $191(73.7 \%)$ & \\
\hline
\end{tabular}

Note: ${ }^{*}$ chi-square test. $P<0.05$ value; **Bazil Economic Classification Criterion of the Brazilian Association of Research Companies, 2015. 
Table 2 - Percentage distribution of women regarding mammography according to the age group of Cruzeiro do Sul and Rodrigues Alves, Acre, Brazil, 2017-2018

\begin{tabular}{|c|c|c|c|c|c|c|}
\hline & \multicolumn{2}{|c|}{35 to 39 years } & \multicolumn{2}{|c|}{40 to 49 years } & \multicolumn{2}{|c|}{50 to 69 years } \\
\hline & Cruzeiro do Sul & Rodrigues Alves & Cruzeiro do Sul & Rodrigues Alves & Cruzeiro do Sul & Rodrigues Alves \\
\hline \multicolumn{7}{|l|}{ Have undergone mammography } \\
\hline No & $152(92.1 \%)$ & $58(89.2 \%)$ & $123(67.2 \%)$ & $48(75.0 \%)$ & $116(58.0 \%)$ & $32(54.2 \%)$ \\
\hline Yes & $13(7.9 \%)$ & $7(10.8 \%)$ & $60(32.8 \%)$ & $16(25.0 \%)$ & $83(41.5 \%)$ & $27(45.8 \%)$ \\
\hline Do not remember & - & - & - & - & $1(0.5 \%)$ & - \\
\hline TOTAL & 165 & 65 & 183 & 64 & 200 & 59 \\
\hline${ }^{*} p$ value & \multicolumn{2}{|c|}{0.6595} & \multicolumn{2}{|c|}{0.3142} & \multicolumn{2}{|c|}{0.7324} \\
\hline \multicolumn{7}{|l|}{$\begin{array}{l}\text { Frequency with which undergo } \\
\text { mammography }\end{array}$} \\
\hline Annually & $3(23.1 \%)$ & $3(42.9 \%)$ & $16(26.7 \%)$ & $10(62.5 \%)$ & $16(19.3 \%)$ & $7(25.9 \%)$ \\
\hline Every two years & $1(7.7 \%)$ & $1(14.3 \%)$ & $5(8.3 \%)$ & - & $6(7.2 \%)$ & - \\
\hline Every three years & - & - & - & - & $1(1.2 \%)$ & - \\
\hline In interval $\geq$ to 3 years & - & - & - & - & $2(2.4 \%)$ & $1(3.7 \%)$ \\
\hline At interval $\leq$ to 1 year & - & - & - & $1(6.3 \%)$ & $2(2.4 \%)$ & $1(3.7 \%)$ \\
\hline Do without following a periodicity & $9(69.2 \%)$ & $3(42.9 \%)$ & 35 (58.3\%) & $5(31.3 \%)$ & $50(60.2 \%)$ & $11(40.7 \%)$ \\
\hline Do not remember & - & - & $4(6.7 \%)$ & - & $6(7.2 \%)$ & $7(25.9 \%)$ \\
\hline TOTAL & 13 & 7 & 60 & 16 & 83 & 27 \\
\hline${ }^{*} p$ value & \multicolumn{2}{|c|}{0.4049} & \multicolumn{2}{|c|}{0.0178} & \multicolumn{2}{|c|}{0.1289} \\
\hline
\end{tabular}

Note: * chi-squared test. $P<0.05$ value.

Table 3- Percentage distribution of women regarding mammography according to high and standard risk for breast cancer in Cruzeiro do Sul and Rodrigues Alves, Acre, Brazil, 2017-2018

\begin{tabular}{|c|c|c|c|c|}
\hline & \multicolumn{2}{|c|}{ High risk } & \multicolumn{2}{|c|}{ Standard risk } \\
\hline & Cruzeiro do Sul & Rodrigues Alves & Cruzeiro do Sul & Rodrigues Alves \\
\hline TOTAL SAMPLE & 27 & 9 & 188 & 56 \\
\hline \multicolumn{5}{|l|}{ Have undergone mammography } \\
\hline Yes & $10(37 . \%)$ & $5(55.6 \%)$ & $77(41.0 \%)$ & $26(46.4 \%)$ \\
\hline No & $17(63 . \%)$ & $4(44.4 \%)$ & $111(59 . \%)$ & $30(53.6 \%)$ \\
\hline TOTAL & 27 & 9 & 188 & 56 \\
\hline${ }^{*} p$ value & \multicolumn{2}{|c|}{0.443} & \multicolumn{2}{|c|}{0.742} \\
\hline \multicolumn{5}{|l|}{$\begin{array}{l}\text { Frequency with which undergo } \\
\text { mammography }\end{array}$} \\
\hline Annually & $5(50 . \%)$ & $5(100 . \%)$ & $13(16.9 \%)$ & $6(23.1 \%)$ \\
\hline Every two years & $1(10 . \%)$ & $0(. \%)$ & $6(7.8 \%)$ & $0(\%)$ \\
\hline $\begin{array}{l}\text { Do without following a } \\
\text { periodicity }\end{array}$ & $3(30 . \%)$ & $0(. \%)$ & $48(62.3 \%)$ & $11(42.3 \%)$ \\
\hline Other frequency & $1(10 . \%)$ & $0(. \%)$ & $10(13 . \%)$ & $9(34.6 \%)$ \\
\hline TOTAL & 10 & 5 & 77 & 26 \\
\hline${ }^{*} p$ value & & 0.843 & & 0.142 \\
\hline
\end{tabular}

were married, with mixed ethnicity, with low education and belonging to class D-E, data that are similar to those found in other studies already carried out ${ }^{(11,15)}$. The profile of the sample studied is consistent with that of the population of northern Brazil, where most people were social class $D-E^{(16)}$.

Northern Brazil is one of the least developed regions in the country, which concentrates high rates of illiteracy and low income; consequently, it has the lowest Human Development Indexes (HDI) ${ }^{(11,15)}$.
MMG was mentioned by $41.7 \%$ women at high risk and $42.2 \%$ those with standard risk. It was observed that, regardless of the municipalities, $66.7 \%$ of the women at high risk underwent MMG on an annual basis, and Rodrigues Alves obtained a greater range in the number of tests compared to Cruzeiro do Sul. Of the women at standard risk, 57.2\% claim that they undergo the exam without following the appropriate periodicity. MMG performance adequacy occurred only in $7.8 \%$ women at standard risk in Cruzeiro do Sul. In Rodrigues Alves, there was inadequacy regarding the frequency of this examination by all women at standard risk. Therefore, it was found that Cruzeiro do Sul obtained greater follow-up to the guidelines when compared to Rodrigues Alves (Table 3).

\section{DISCUSSION}

Among the sociodemographic characteristics of PHC users in Cruzeiro do Sul and Rodrigues Alves, it was observed that most
These unfavorable sociodemographic aspects can negatively interfere in breast cancer screening due to the difficulty of access and lack of knowledge of early detection methods ${ }^{(13,17)}$.

The finding of low education and social class of BHU users over 50 years old in relation to the younger ones in Cruzeiro do Sul and Rodrigues Alves coincides with the findings of other studies. Greater social vulnerability was evidenced in this age group and greater attention and effort was required of health professionals and managers to improve the offer and access to preventive services aimed at women's health ${ }^{(15,17)}$.

In this study, there was an expressive supply of mammograms performed annually among women aged 40 to 49 in Rodrigues Alves compared to Cruzeiro do Sul, with statistically significant results among the municipalities. The performance of MMG in women under 50 and who do not belong to the group at high risk for breast cancer is at odds with the $\mathrm{MoH}$ guidelines. Annual screening, from the age of 40, may also present a greater risk of false-positive results, excessive imaging and biopsies with their 
possible complications. In this age group, screening is also associated with an increased likelihood of developing radio-induced cancer ${ }^{(9)}$. For all these factors, it is important that women are well oriented so that most of them choose not to undergo mammographic screening before 50 years old.

In the six PHC services in the cities studied, $58 \%$ of women at standard risk reported never having undergone a mammogram. These data coincide with the findings of the Brazilian National Household Sample Survey (PNAD - Pesquisa Nacional por Amostra de Domicílio) in 2013, which reveal that, in Brazil, less than a third of women between 50 and 69 years old had never had a screening mammogram, while in the north, this proportion exceeded $50 \%{ }^{(13)}$. States such as Acre, Pará and Tocantins had the highest proportions ${ }^{(18)}$.

In 2010, a study was developed in the municipality of Dourados, state of Mato Grosso do Sul, where 393 registered users in FHS were approached. A frequency of $60 \%$ of CBE and $53.2 \%$ of MMG was observed in women aged 40 to 69 years ${ }^{(19)}$. In Carpina, state of Pernambuco, in 2012, 247 were interviewed, aged between 18 and 88 years, attended by FHS. It was found that $25.5 \%$ of them performed $\mathrm{CBE}$ and $62 \% \mathrm{MMG}^{(10)}$.

It is important to note that, in Cruzeiro do Sul, only $7.8 \%$ of women at standard risk underwent MMG properly, i.e., according to governmental recommendation. The situation is even more aggravating in Rodrigues Alves, where it was found that the frequency of this test was inadequate in all women in the group at standard risk. In Paraíba, a study was conducted to assess the coverage of screening actions, the results of which indicated that the execution of CBE (58.9\%) and MMG (56.7\%) in the target population was as recommended ${ }^{(20)}$. In a national survey carried out in $2013,54.5 \%$ of screening mammograms in women aged 50 and 69 were considered adequate with regard to frequency ${ }^{(13)}$.

Screening is a procedure performed in $\mathrm{PHC}$, and professionals working there must know this method, the frequency and the recommended target population. They must know how to guide women, for whom screening is indicated, about the possible benefits and harms associated with this screening in a shared decision process ${ }^{(9)}$. In the present study, the percentage of mammograms performed on women at standard risk in both cities was $42 \%$; of these, $57.2 \%$ undergo the exam without following the appropriate periodicity, $18.4 \%$, annually and $5.8 \%$, biennial.

Different findings from a study conducted with data from SISMAMA (Sistema de Informação do Câncer de Mama - Breast Cancer Information System), from 2010 to 2011, demonstrate that among screening MMG 51.2\% were performed on women aged 50 to 69 years, with a strong predominance (45\%) of annual or less, and $32 \%$ between one and two years ${ }^{(21)}$. Another study carried out in southern Brazil between 2013 and 2014, with 525 women, found that SUS users were subjected to annual screening more frequently (62\%) than those with health plans (48\%) ${ }^{(22)}$.

Other studies have shown that lack of training and updating of many health professionals leads them to implement actions that are not in line with what is advocated in public policies for breast cancer screening. Studies suggest flaws or lack of knowledge of professionals working at PHC in relation to screening procedures $^{(7,23)}$.

$\mathrm{PHC}$ is characterized as a privileged place for implementing educational actions. In this way, PHC professionals have a fundamental role in the development of these actions, especially the nurse, considered the main articulator between the health team and service users ${ }^{(24)}$.

\section{Study limitations}

This study presents, as possible limitations, the memory bias in issues that required interviewees to make a retrospective of past facts.

\section{Contributions to nursing, health, and public policies}

It is believed that the data from the present research will assist managers and health professionals in planning strategies to face the problems identified based on reality data and will contribute to analysis of compliance of early breast cancer detection actions. Based on the results obtained, it is necessary to elaborate a municipal protocol aimed at women's health that considers national recommendations, providing an improvement in the conduct of professionals in relation to breast cancer screening.

\section{CONCLUSION}

The data of this investigation demonstrate that even implementing current public policies aimed at breast cancer control, early detection actions did not reach the majority of women with standard risk in the recommended periodicity, resulting in low compliance with the $\mathrm{MoH}$ recommendation. This finding needs to be presented and discussed with managers and health professionals and users of PHC services in these municipalities, and based on this communication, goals can be developed and agreed upon in order to achieve better results in controlling this disease.

\section{REFERENCES}

1. Bray F, Ferlay J, Soerjomataram I, Siegel RL, Torre LA, Jemal A. Global Cancer Statistics 2018: GLOBOCAN estimates of incidence and mortality worldwide for 36 cancer in 185 countries. Cancer J Clin. 2018;68(6):394-424. https://doi.org/10.3322/caac.21492

2. Instituto Nacional de Câncer José Alencar Gomes da Silva (INCA). A situação do câncer de mama no Brasil: síntese dos dados dos sistemas de informação [Internet]. Rio de Janeiro: INCA; 2019 [cited 2019 Aug 2]. Available from: https://www.inca.gov.br/sites/ufu.sti.inca.local/ files//media/document//a_situacao_ca_mama_brasil_2019.pdf

3. Girianelli VR, Gamarra CJ, Azevedo e Silva G. Os grandes contrastes na mortalidade por câncer do colo e de mama no Brasil. Rev Saúde Pública. 2014;48: 459-67. https://doi.org/10.1590/S0034-8910.2014048005214 
4. Azevedo e Silva G, Bustamante-Teixeira MT, Aquino EML, Santos-Silva I. Acesso à detecção precoce do câncer de mama: uma análise a partir dos dados do sistema de informação em saúde. Cad. Saúde Pública. 2014;30(7):1537-50. https://doi.org/10.1590/0102-311X00156513

5. Romeiro-Lopes TC, Gravenab AAF, Dell'Agnoloc CM, Pires IHV, Rocha-Brischiliarie SC, Borghesana DHP, et al. Cobertura estimada de mamografia no estado do Paraná. Ciênc Saúde. 2015;8(2):48-53. https://doi.org/10.15448/1983-652X.2015.2.20219

6. Renna Jr LN, Azevedo e Silva G. Late-Stage Diagnosis of Breast Cancer in Brazil: anallysis of data from hospital-based cancer registries(2000-2012). Rev Bras Ginecol Obstet. 2018;40:127-36. https://doi.org/10.1055/s-0038-1624580

7. Costa FML, Enders BC. Actions of professionals of the family health strategy in early detection of breast câncer. Rev Enferm UFPE. 2014;8(7):2061-8. https://doi.org/0.5205/reuol.5963-51246-1-RV.0807201430

8. Instituto Nacional de Câncer José Alencar Gomes da Silva(INCA). Controle do câncer de mama. Documento de Consenso [Internet]. Brasília: INCA; 2004[cited 2016 May 4]. Available from: http://bvsms.saude.gov.br/bvs/publicacoes/Consensointegra.pdf

9. Instituto Nacional de Câncer José Alencar Gomes da Silva(INCA). Diretrizes para a detecção precoce do câncer de mama no Brasil [Internet]. Rio de janeiro: INCA; 2015[cited 2016 Jun 10]. Available from: inca.gov.br/sites/ufu.sti.inca.local/files//media/document//diretrizes_ deteccao_precoce_cancer_mama_brasil.pdf

10. Bushatsky M, Lima KD, Moraes LX, Gusmão LT, Barros MB, Figueira Filho AS. Breast cancer: prevention of shares in primary health care. Rev Enferm UFPE. 2014;8(10):3429-36. https://doi.org/10.5205/reuol.6039-55477-1-ED.0810201422

11. Sadovsky ADI, Poton WL, Reis-Santos B, Barcelos MRB, Silva ICM. Índice de Desenvolvimento Humano e prevenção secundária de câncer de mama e colo do útero: um estudo ecológico. Cad. Saúde Pública. 2015;31(7):1539-50. https://doi.org/10.1590/0102-311X00073014

12. Kuhn FS, Santana AIC, Mêrces MC. Produção de mamografias no âmbito do Sistema Único de Saúde. Rev Saúde Pesqui. 2018;11(2):231-7. https://doi.org/10.177651/1983-1870.2018v11n2p231-237

13. Theme Filha MM, Leal MC, Oliveira EFV, Pereira APE, Gama SGN. Regional and social inequalities in the performance of Pap test and screening mammography and their correlation with lifestyle: Brazilian National Health Survey, 2013. Int J Equity Health. 2016. https://doi. org/10.1186/s12939-016-0430-9.

14. Marques CAV, Figueiredo EN, Gutiérrez MGR. Validation of an instrument to identify actions for screening and detection of breast cancer. Acta Paul Enferm. 2015;28 (2):183-9. https://doi.org/10.1590/1982-0194201500031

15. Szwarcwald CL, Souza Jr PRB, Marques AP, Almeida WS, Montilla DER. Inequalities in healthy life expectancy by Brazilian geographic regions: findings from the National Health Survey, 2013. Int J Equity Health. 2016;15:141. https://doi.org/10.1186/s12939-016-0432-7

16. Associação Brasileira de Empresa de Pesquisa. Critério de Classificação Econômica (ABEP)[Internet].2015[cited 2016 Feb 15]. Available from: http://www.abep.org/criterio-brasil

17. Silva NC, Rocha $T A H$, Rodrigues RB, Barbosa ACQ. Equidade na Atenção Primária à Saúde da mulher: uma análise do Brasil e suas regiões. Rev Baiana Saúde Pública. 2014;38(2):243-65. https://doi.org/10.5327/Z0100-0233-2014380200003

18. Instituto Brasileiro de Geografia e Estatística (IBGE). Pesquisa nacional de saúde: 2013: ciclos de vida: Brasil e grandes regiões. Coordenação de Trabalho e Rendimento [Internet]. Rio de Janeiro: IBGE; 2015 [cited 2016 Feb 9]. Available from: https://biblioteca.ibge.gov.br/ visualizacao/livros/liv94522.pdf

19. Batiston AP. Early detection of breast cancer: knowledge and practice of women and professionals of the Family Health Strategy in Dourados/ MS. Rev Bras Ginecol Obstetr [Internet]. 2010 [cited 2018 Nov 6];32(2):99. Available from: http://www.scielo.br/pdf/rbgo/v32n2/ v32n2a10.pdf

20. Barreto ASB, Mendes MFM, Thuler LCS. Evaluation of a strategy adopted to expand adherence to breast cancer screening in Brazilian Northeast. Rev Bras Ginecol Obstetr [Internet]. 2012 [cited 2018 Nov 6];34(2):86-91. Available from: http://www.scielo.br/pdf/rbgo/v34n2/ a08v34n2.pdf

21. Tomazelli JG, Migowski A, Ribeiro CM, As $\neg$ sis M, Abreu DM. Assessment of actions for breast cancer early detection in Brazil using process indicators: a descriptive study with Sismama data, 2010-2011. Epidemiol Serv Saúde. 2017;26:61-70. https://doi.org/10.5123/ s1679-49742017000100007

22. Lopes TCR, Franca Gravena AA, De $\neg$ mitto MO, Brischiliari SC, Borghesan DH, Dell Agnolo CM, et al. Mammographic screening of women attending a reference service cen $\neg$ ter in Southern Brazil. Asian Pac J Cancer Prev. 2016;17:1385-91. https://doi.org/10.7314/APJCP2016.17 3.1385

23. Melo FBB, Marques CAV, Rosa AS, Figueiredo EN, Gutiérrez MGR. Actions of nurses in early detection of breast cancer. Rev Bras Enferm. 2017;70(6):1119-28. https://doi.org/10.1590/0034-7167-2016-0155

24. Lourenço TS, Mauad EC, Vieira RAC. Barreiras no rastreamento do câncer de mama e o papel da enfermagem: revisão integrativa. Rev Bras Enferm. 2013;66(4):585-91. https://doi.org/10.1590/S0034-71672013000400018 